\title{
ANALYSIS OF THE ACCOUNTING SYSTEM OF RAW MATERIALS PURCHASES AND CASH DISBURSEMENTS AS AN EFFORT TO IMPROVE INTERNAL CONTROLS: A STUDY IN PT OTSUKA INDONESIA
}

\author{
Dzulkirom AR M. \\ Faculty of Administrative Sciences, University of Brawijaya, Malang, Indonesia \\ *E-mail: dzulkirom.m@ub.ac.id
}

\begin{abstract}
This research aims to analyze the internal controls support in the implementation of the raw materials purchases and cash disbursements systems in PT. Otsuka Indonesia. The purchases system is one part of the accounting system used in companies to make all raw materials purchases. The purchases process aims to make a procurement of raw materials for the production process of the finished products. The implementation of the purchases system is closely related to cash disbursements because every purchase transaction will cause the cash disbursements system. Every system in companies requires internal controls to maintain the accuracy of the data and protect the company's assets. This research uses the descriptive method with a qualitative approach. Data were obtained from primary and secondary data and collected through interviews and documentation tested for validity using triangulation. The research results show that the raw materials purchases and cash disbursements systems as an effort to improve internal controls are good enough but still has some weaknesses, i.e. multiple functions, incomplete documents, and inadequate internal controls implementation. The company needs to improve its systems by segregating functions according to the duties and responsibilities, completing documents for audit trails information, and improving its internal control.
\end{abstract}

\section{KEY WORDS}

Accounting system, raw materials purchases, cash disbursements, internal control.

The businesses development which opens the opportunities in this globalization era has resulted in the emergence of various problems. One of them is an increasingly complex operational problem in companies. Companies are the organization that produces services and goods for profit. Competition in the business world makes companies must be able to follow the current changes and developments, one of which establishes a system in accordance with conditions with the aim of maintaining survival and operational activities.

According to Mulyadi (2016), "system is procedures made in an integrated pattern to run the company's main activities". One of the most important systems in companies is the accounting system. Mulyadi (2016) defines the accounting system as "the management of records, documents, and reports coordinated as best as possible to provide financial information needed by the organization to facilitate the company management". One system which needs to be developed is the purchases system. This system plays an important role in the procurement of goods needed for the company sustainability.

The raw materials purchases process in companies is the most important process to produce the finished products to be sold by companies. The mismatch of the available raw materials and those required by companies can lead to disruption of the production process. Therefore, the purchases system is made to facilitate companies in the tasks and responsibilities segregation and to ensure the related functions in the raw materials purchases can be effectively interconnected. According to Mulyadi (2016), "The purchases system in companies aims to make the procurement of goods needed by companies".

The purchases system is used to ensure the raw materials purchases process run efficiently and effectively to prevent various practices which can cause the company losses. The purchases system is used to deal with various problems related to the raw materials purchases in companies. The most occurring problem in manufacturing companies related to 
the raw material purchases system is the raw materials purchases at high prices due to the inappropriate system application to anticipate price increases. Price increases occur because of the mismatch of available raw material and those required. The unavailability can be caused by erratic weather which makes these raw materials difficult to be managed.

The implementation of the purchases system is closely related to cash disbursements. Every purchase transaction in companies will cause the cash disbursements system. According to Krismiaji (2010), "The cash disbursements process is business and data processing activities related to purchases and transaction payments for purchased goods and services".

Every system in companies certainly needs internal controls. Ranatarisza and Noor (2013) state that "Internal controls are the process of monitoring, directing, and measuring the organization or company resources". Internal controls in companies include transactions authorization, segregation of duties, supervision, accounting records, access control, and independent verification.

Internal controls of the raw materials purchases and cash disbursements systems are very important. Internal controls can increase the companies' operational efficiency because it can maintain the accuracy of various data and protect the company's assets. Internal controls are needed in the raw materials purchases and cash disbursements to minimize and prevent problems in the raw materials purchases and cash disbursements systems.

This research was conducted in PT. Otsuka Indonesia because the company is a pharmaceutical manufacturing company whose main activity is processing raw materials into finished products. Manufacturing companies certainly have complicated raw materials purchases and cash disbursements systems, so the researchers aim to develop a better system to be implemented and manage a more adequate assessment according to the theory because mistakes will result in huge losses.

\section{LITERATURE REVIEW}

System and Procedure Concept. According to Ranatarisza and Noor (2013), "The system is a set of components which are interconnected and interacted in managing activities to achieve a goal". Mulyadi (2016) defines "Procedure as a sequence of clerical activities, usually involving several people in one department or more, which is made to ensure uniform handling of repeated organizational transactions".

Accounting System. "An accounting system is a network consisting of documents, records, procedures, tools, and human resources to produce information in an organization for the purpose of monitoring, operating, and business decision making" (Narko, 2007).

Purchases System. According to Mulyadi (2016), the purchases system in companies aims to make the procurement of goods needed by companies. According to Hall (2009), the main difference lies in the way various transactions are authorized. Manufacturing companies buy raw materials for production. The purchasing decisions are authorized by the production planning and control function. Hall (2009) asserts the components of raw materials demand are sales forecasts, inventory status reports, technical specifications for finished goods, products based on orders, raw materials specifications, and operations. These components are very important for the detailed analysis needed to make BOMs and route sheets. Standard products can make BOMs and route sheets in advance to be stored so that administrative staff can withdraw the documents only when needed, making the complexity of the production stage can be reduced.

According to Hall (2009), several functions related to the purchases system include:

- Inventory Control;

- Purchasing Department;

- Receiving Department;

- Accounts Payable Department;

- Ledger Department.

According to Hall (2009), the needed documents for the raw materials purchases in the production planning and control function are: 
- Sales Forecasts;

- Bill of Materials;

- Route Sheets;

- Inventory Status;

- Technical Specifications.

According to Hall (2009), other documents used in the purchases system are:

- Purchase Requisition Letter;

- Purchase Order Letter;

- Blind Copy of the Purchase Order;

- Receiving Report;

- Supplier's Invoice.

According to Hall (2009), the records used in the purchases system are:

- Purchases journal;

- Accounts payable subsidiary ledger;

- Proof of purchases journal;

- Ledger.

According to Hall (2009), the procedures of the purchases system include:

- Purchase requisition;

- Purchase order;

- Inventory receipt;

- Accounts payable.

Cash Disbursements System. According to Krismiaji (2010), the cash disbursements system is a series of business and data management activities related to purchases and payments for purchased goods and services. According to Hall (2009), the functions related to the cash disbursements system with checks are:

- Accounts payable department;

- Cash disbursements department;

- Ledger department.

According to Hall (2009), the function related to the cash disbursements system with the check is the check, along with the supporting documents, goes to the cash disbursements department manager, or treasurer, for his or her signature. According to Hall (2009), the function related to the cash disbursement system with the check is the cash disbursements journal.

According to Hall (2009), the procedures of the purchases system are:

- The accounts payable process reviews the accounts payable file for documents that have come due and authorizes the cash disbursement process to make payments.

- Cash disbursements process makes and distributes checks to suppliers. Copies of various checks will be returned to the accounts payable department as proof of payment and the accounts payable record will be updated.

- At the end of the period, both cash disbursement and accounts payable processes send summary information to the general ledger. This information is reconciled and recorded into cash and accounts payable control accounts.

Internal Controls System. According to Ranatarisza and Noor (2013), internal controls are the process of monitoring, directing, and measuring the organization or company resources. According to Hall (2009), the components of internal controls are:

- Transaction authorization. The purpose of transaction authorization is to ensure that transactions processed by the information system are valid and in accordance with management's objectives.

- Segregation of duties. One of the most important control activities is the segregation of employee duties to minimize incompatible functions. The authorization for a transaction is separate from the processing of the transaction and responsibility for the custody of assets should be separate from the record-keeping responsibility. 
- Supervision. Supervision is needed for small companies with inadequate segregation of duties.

- Accounting records. Company accounting records consist of source documents, journals, and ledgers as providers of audit trail information from various transactions. This information is needed to carry out daily operations and allow the auditor to track any transaction through all process stages from the beginning of the event to the financial statements.

- Access control. The purpose of access control is to ensure that only authorized personnel have access to the company's assets. Access controls play an important role in safeguarding assets. Access to assets can be direct or indirect. Physical security tools control direct access, while indirect access to assets is accomplished by segregating the duties of employees who must access and process various records.

- Independent verification. It means the independent checks of the accounting system to identify misrepresentations.

\section{METHODS OF RESEARCH}

This research uses the descriptive method with a qualitative approach. The study was conducted in PT. Otsuka Indonesia located at Jalan Sumber Waras no. 25 Kalirejo Village, Lawang Sub-district, Malang Regency, East Java. PT. Otsuka Indonesia is a pharmaceutical manufacturing company that manufactures and sells various medicines, infusions, and medical tools. Data were obtained from primary and secondary data and collected through interviews and documentation. The instruments used interview guidelines and documentation guidelines tested for the data validity using triangulation. The steps used for data analysis in this research are:

Analyzing the implementation of the accounting system for raw materials purchases and cash disbursements in PT. Otsuka Indonesia. Analyzing functions related to the raw material purchases system in PT. Otsuka Indonesia, which includes:

Analysis of functions related to the purchases system;

- Analysis of documents used in the purchases system;

- Analysis of records used in the purchases system;

- Procedures in the purchases system;

- Analysis of documents related to the cash disbursements system, i.e. checks;

- Analysis of records related to the cash disbursements system, i.e. the cash disbursements journal;

- Procedures in the cash disbursements system.

Analyzing internal controls for the accounting systems of raw material purchases and cash disbursements, i.e.:

- Analyzing transaction authorization in PT. Otsuka Indonesia related to ensuring that transactions processed by the system are in accordance with the management's objectives.

- Analyzing segregation of duties related to the segregation of employee duties to minimize and eliminate incompatible functions.

- Analyzing supervision related to the asset control.

- Analyzing accounting records related to the process stage of source documents, journals, and ledgers from the beginning of transactions to financial statements.

- Analyzing access control to ensure that only authorized personnel have access to company assets.

- Analyzing independent verification related to independent checks of accounting systems to identify misrepresentations. 


\section{RESULTS AND DISCUSSION}

\section{Implementation Analysis in the Purchases System:}

Related Functions:

- PPIC (Production Planning and Inventory Control) function. PPIC function in PT. Otsuka Indonesia is not good enough in running its responsibilities, i.e. making production planning, Bill of Materials, and purchase requisition documents. This function is also responsible for submitting inventory requests in accordance with production planning and for controlling inventory. These duties should be separated. The production planning and control function should only be responsible for planning the inventory needs and making purchase requisitions, while the inventory control function should only be responsible for reviewing the raw material inventory to make inventory status. The company is advised to segregate the duties to make each function focuses on their duties.

- Purchasing function. Purchasing function in PT. Otsuka Indonesia is good in managing its responsibilities to receive the purchase requisition documents and to make purchase order documents.

- Material Warehouse Function. The Material Warehouse function is still not good in administering its responsibilities to make documents (the receiving reports) after receiving the delivery order from the suppliers. It results in the risk of employee fraud by misusing the company property. The documents should be made by the quality control function after conducting an inspection by reconciling the delivery order with the blind copy of the $\mathrm{PO}$, while the material warehouse function should only store the raw materials.

- Quality Control Function. The Quality Control function is still not good in managing its responsibilities. This function does not make receiving report documents stating the quantities and condition of raw materials upon arrival of goods. This results in the risk of employee fraud by misusing the company's assets. It is better not to give the responsibility for making the receiving reports to the warehouse function when supplies arrive.

- Account and Payable function. Account and Payable function is good enough in organizing its responsibilities to receive and temporarily store various copies of purchase orders and receiving reports, but it is recommended that the delivery order records are replaced with the purchase requisition documents.

- Accounting Function. The ledger department is very good in administering its responsibilities. This department records from the journal to the inventory and accounts payable accounts and reconciles the inventory control accounts and the inventory subsidiary summary.

Documents Used:

- Sales forecasts. These documents are most important in the production planning. The use is very good to show the estimated demand for finished goods every month.

- Bill of materials. These documents are the same as the list of raw material requirements. The use is good because they include the item name, description, needed amount, unit, information, and date needed.

- Route sheet. These documents are good in indicating the sequence and the time of machining operations allocated to each task.

- Inventory status. Inventory status documents are the same as warehouse cards with good usage in indicating the final condition of raw materials after a reduction has been made for production use. These documents should be made by the inventory control function.

- Technical specifications. The technical specifications documents have good usage in providing complete requirements information regarding the final products that can be purchased. Purchase requisition documents - These documents are made by the PPIC function which should be made by the production planning and control function, 
while inventory control only shows the final condition of raw materials. These documents contain the request number, supplier name, request date, date needed, name of the purchasing agent, item name, quantity, unit type, unit price, and total cost. These documents are not sent to the accounts payable function to be used as the archive or reconciliation. This is a risk for the purchasing function because it can make purchases not in accordance with the planning without the authorization from the PPIC function and the risk of accounts payable function for assets misuse. The company should copy these documents to be used as the archive or reconciliation for other functions.

- Purchase order document. These documents have a quite good usage because they clearly specify the unit type, quantity, and price, but the documents are only made in three copies for archives, accounting function, and suppliers. These documents should be copied for the production planning and control function, the receiving function, the accounts payable function, archives, and two copies for suppliers to avoid misuse.

- Delivery order. Delivery order documents are the same as the packing slip documents. The usage is good because they show the item name, quantity, purchase order number signed by the sender and recipient. Documents sent to the receiving department are written with invoices and do not show the price to prevent fraud.

- Receiving reports. These documents are good enough because they show the supplier name, purchase order number, date, item number, unit type, quantity, name of the purchasing agent, and serial location. However, it is necessary to add information on the item condition and the name of the receiving staff. These documents should be made by the quality control function after inspecting the arrival of the goods.

- Invoice. The invoice is good because it shows the delivery order number, item, description, quantity, currency, price, total, term of payment date, and signature from the accounting staff.

Records used:

- Purchase journal. This record has been used very well because the information consists of date, supplier name, invoice number, debit of inventory control account, accounts payable subsidiary ledger, account recording, accounts payable credit, and refund returns.

- Accounts payable subsidiary ledger. The usage is very good because it includes information about the supplier code number, name, date, transaction, debit, credit, and balance.

- Proof of general journal. The records are made by the accounts payable department to summarize the verses from the purchase journal in that period to be sent to the general ledger department.

- Ledger. The ledger is very good because it includes the information about the account, debit, and credit overview.

- Procedures in the Raw Materials Purchases System. Raw materials purchases procedure in PT. Otsuka Indonesia is good enough, but there are still some weaknesses. A description of the recommended raw material purchases system procedure is as follows:

- Purchase requisition. The purchase procedure starts from the PPIC function to do production planning. This planning should be executed by the production planning and control function, while the inventory control function reviews the raw material inventory to make inventory status documents. The function is responsible for making purchase requisitions based on sales forecasts, production capacity, route sheets, technical specifications, and inventory status documents. Purchase requisitions can sometimes be delayed due to the scarcity of raw material supplies. The raw materials scarcity has resulted in rising prices on the market. However, after the raw materials are available with abundant quantity, PT. Otsuka Indonesia purchases more than 
previously planned purchase requisitions. Planning based on forecasts should not focus only on sales forecast, but also focus on how to fulfill the raw materials. The company is advised to separate between production planning and control and inventory control to make each function focuses more on their responsibilities.

- Purchase orders. Purchase orders are made by the purchasing function. Documents used for purchase orders are copied in triplicate to be sent to suppliers, accounting function, and archives at the purchasing function. This results in the receiving department making PO Material receipt only by checking the delivery order from the supplier without cross-checking with the purchase order document which results in a risk of shipping errors. These documents are also not sent to PPIC as the archive. It is better for documents to be sent to the receiving function and PPIC to avoid the possible risks.

- Inventory receipt. The receiving function does not accept purchase order archives from the purchasing function. The PO Material receipt should be made if there is a blind copy of the purchase order and the delivery order documents to be examined simultaneously. PO receipt documents should be made in the Quality Control function because the arrival of raw materials in the warehouse material does not guarantee the quality. The receiving function also sends the receiving report to the inventory control function to update existing inventory records.

- Accounts payable. Accounts payable procedure is good enough, but the delivery order document should not be sent to the finance department to be more effective.

Implementation Analysis on the Cash Disbursements System:

Related Functions:

The cash disbursements function is very good because there are three interrelated functions, i.e. accounts payable, finance and cashier, and accounting.

Documents Used:

Check documents in cash disbursements is very good. The company already used the application to approve transactions.

Records used:

Cash disbursements journals are very good in providing complete information.

Procedures in the Cash Disbursements System:

The cash disbursements procedure applied is good enough but the company should replace the delivery orders with purchase requisition documents on the accounts payable file because the delivery orders are only used temporarily and the receiving reports are more than enough to complete the required information.

Analysis of Internal Controls for the Accounting System of Raw Materials Purchases and Cash Disbursements:

Transaction authorization:

- Purchases subsystem. Transaction authorization on purchase requisitions in PT. Otsuka Indonesia is not good because of the formalization of the authorization process in the Production Planning and Inventory Control function. Authorization should be made by the production planning and control function to reassure efficient inventory management and ensure the authorization of various purchase transactions. This stage makes the purchasing function unable to buy inventory without the authorization of production planning and control function or unplanned purchases and can avoid excess raw materials purchases.

- Cash disbursements subsystem. Authorization of cash disbursements in PT. Otsuka Indonesia is very good because of the formalization of the authorization process on the accounts payable function.

- Segregation of Duties. Segregation of inventory control from the warehouse. Internal control on the segregation of duties in PT Otsuka Indonesia is still not good because there is no inventory control function. This function is still concurrent with the production planning and control function. The company should make an inventory control function and separate the function from the production planning and control 
and warehouse so that the transactions authorization is separated from the transaction processing. Segregation of the ledger and accounts payable from cash disbursements. Internal control on the segregation of duties in the cash disbursements system in PT. Otsuka Indonesia is good because of accounts payable, finance and cashier, and accounting functions are separated.

Supervision is carried out to avoid checking failure and theft of assets:

- Inspection of assets. The Quality Control function should reconcile blind copy when inventory arrives, inspect items, and make receiving reports, while warehouse material has custody.

- Theft of Assets. PT. Otsuka Indonesia avoids theft of assets by securing inventory stored in the warehouse material.

- Accounting records. Internal controls regarding accounting records for the purchases and cash disbursements systems are good, among other: records control of the purchases system is good in providing the audit trails of various transactions; records control of the cash disbursements system is good in providing audit trails information by storing various transaction records.

Access controls:

- Direct access. Direct access controls is good because it uses alarms, locks, and restricted access.

- Indirect access. Indirect access controls is good because access has been limited such as segregating the duties of employees who must access and process the records.

Independent verification. Independent verification by the accounts payable department/ Internal controls in the accounts payable department is good enough in the verification by reconciling various documents before recognizing liabilities. The documents include:

- Delivery orders. These documents show the various transactions that have been authorized for inventories needed by the company but should not be sent to the account and payable department.

- Purchase order. The PO documents have been verified properly.

- Receiving report. These documents have been poorly verified because they show that the supplies received are not necessarily in accordance with the conditions and quantities ordered. The company should carry out valid liability if it has reconciled the blind copy of the PO with the delivery document made by the Quality Control function.

- Supplier's Invoice. These documents have been verified very well.

- Independent verification by ledger department. Verification by the ledger department is good in terms of the Production Planning and Inventory Control function, accounts payable, and cash disbursements. The department verifies total liabilities recorded are equal to the inventory received and the total reduction in accounts payable equals the cash disbursements.

\section{CONCLUSION}

The results of the data analysis of the accounting system of raw materials purchases and cash disbursements and internal controls in PT. Otsuka Indonesia show that the implemented systems is good enough, but still does not support maximum internal control due to some weaknesses. The following is a description of the various weaknesses in PT. Otsuka Indonesia:

- PT. Otsuka Indonesia in implementing the accounting system of raw materials purchases and cash disbursements is still not good, because there is a multiple function in the Production Planning and Inventory Control function, the warehouse function makes the receiving reports, and the delivery orders are sent to the accounts payable department in the purchases and cash disbursements systems.

- Application of internal controls in the raw materials purchases and cash disbursements systems in PT. Otsuka Indonesia is still not good because the 
purchase authorization is still in the Production Planning and Inventory Control function, there is no segregation of duties in the Inventory Control function, supervision on asset inspection still makes the receiving reports when the inventory arrives in the warehouse, and verification still sends the delivery orders without sending the purchase requisitions to the accounts payable department.

\section{SUGGESTIONS}

Based on these conclusions, there are several suggestions expected to be useful for PT. Otsuka Indonesia, i.e.:

- In implementing the raw material purchases system, it is suggested that PT. Otsuka Indonesia should separate between production planning and control function with inventory control function to avoid wrongdoings and to focus more on each responsibilities. Besides, Quality Control should make the receiving reports when supplies arrive. Other suggestions are delivery orders should not be sent to the accounts payable department due to the presence of the receiving reports with more detailed information and the purchase requisition documents should be sent to the accounts payable so that it can be reconciled with a purchase order to avoid misuse of inventory purchases.

- For the implementation of internal controls, PT. Otsuka Indonesia should give the authorization for production planning and control only and segregate the duties with the inventory control function to avoid misuse of inventory purchases. Another suggestion is supervision on asset inspection. Quality Control should make the receiving reports and verifies using purchase requisition documents to be reconciled with purchase order documents in the accounts payable department.

\section{REFERENCES}

1. Hall, J. A. (2009). Sistem Informasi Akuntansi. Translated by Fitriasari., Dewi., and Deni, A. K. Jakarta: Salemba Empat.

2. Krismiaji. (2010). Sistem Informasi Akuntansi. Yogyakarta: UPP UMP YKPN.

3. Mulyadi. (2016). Sistem Akuntasi. Jakarta: Salemba Empat.

4. Narko. (2007). Sistem Akuntansi. Yogyakarta: Yayasan Pustaka Nusatama.

5. Ranatarisza, M. M., and Maz, A. N. (2013). Sistem Informasi Akuntansi pada Aplikasi Administrasi Bisnis. Malang: UB Press. 